\begin{tabular}{|l|l|l||}
\hline \multicolumn{2}{|c|}{ PublisherInfo } \\
\hline \hline PublisherName & $:$ & BioMed Central \\
\hline \hline PublisherLocation & $:$ & London \\
\hline \hline PublisherImprintName & $:$ & BioMed Central \\
\hline \hline
\end{tabular}

\title{
Wood genomics
}

\begin{tabular}{|l|l|l||}
\hline \multicolumn{2}{|c|}{ ArticleInfo } \\
\hline \hline ArticleID & $:$ & 4268 \\
\hline \hline ArticleDOI & $:$ & $10.1186 /$ gb-spotlight-20011203-01 \\
\hline \hline ArticleCitationID & $:$ & spotlight-20011203-01 \\
\hline \hline ArticleSequenceNumber & $:$ & 339 \\
\hline \hline ArticleCategory & $:$ & Research news \\
\hline ArticleFirstPage & $:$ & 1 \\
\hline \hline ArticleLastPage & $:$ & 2 \\
\hline \hline & $:$ & RegistrationDate : 2001-12-03 \\
ArticleHistory & $:$ & OnlineDate \\
\hline \hline ArticleCopyright & $:$ & BioMed Central Ltd2001 $12-03$ \\
\hline \hline ArticleGrants & $:$ & \\
\hline \hline ArticleContext & $:$ & 130592211 \\
\hline \hline
\end{tabular}




\section{Jonathan B Weitzman}

Email: jonathanweitzman@hotmail.com

The wood-forming tissues of trees offer an attractive experimental system in which to correlate tissuespecific expression with stages in a defined developmental gradient. In the December 4 Proceedings of the National Academy of Sciences, Magnus Hertzberg and co-workers from the Umeå Plant Science Center in Umeå, Sweden, describe a transcript-profiling study of xylogenesis in poplar trees (Proc Natl Acad Sci USA 2001, 98:14732-14737). They collected tangential sections across the wood development region in Populus tremula X Populus tremuloides (hybrid aspen). Samples were hybridized to cDNA microarrays containing nearly three thousand unique ESTs from hybrid aspen. Hierarchical clustering allowed them to define 539 genes grouped into classes with developmentally regulated expression patterns. Genes expressed in the cambial meristem and early expansion zones encode regulators of cell cycling, cell expansion, tip growth, and primary cell wall biosynthesis. The regions involved in late expansion and secondary cell-wall biosynthesis express genes encoding tubulins, cellulose synthase, sucrose synthase, and enzymes for pectin and lignin biosynthesis. Analysis of over 500 sequences that correspond to Arabidopsisproteins of unknown function should provide clues about gene function and their role in wood formation.

\section{References}

1. Auxin as a positional signal in pattern formation in plants.

2. Proceedings of the National Academy of Sciences, [http://www.pnas.org]

3. Umeå Plant Science Center, [http://www.upsc.nu/]

4. cDNA microarray analysis of small plant tissue samples using a cDNA tag target amplification protocol. 